\title{
Paths to Decolonization in the French Caribbean: Aimé Césaire and Frantz Fanon Naregh Galoustian
}

Naregh Galoustian is a $4^{\text {th }}$ year student majoring in History and Political Science. He previously studied French and Russian literature in Italy. His current focus is on the intersections between the intellectual and political history of the Caribbean and Latin America, especially in terms of nation, race and citizenship. He strives to explore the shared experiences found in history in order to connect diverse and apparently divergent areas. He is currently working as a project manager at an international media development organization focusing on human rights.

Abstract: In the Caribbean, national independence traditionally meant formal decolonization. However, the French Caribbean opted for integration rather than separation from France. Did Martinique and Guadaloupe accept the persistence of colonialism by refusing to gain sovereignty? Although it might seem so, the decision to be integrated within the French departmental system in 1946 stemmed from a longer political history of competing ideas regarding citizenship. In order to better understand this choice and its limits, historical and cultural developments will be explored by referring in broad terms to the thought of two Martinicans: Aimé Césaire and Frantz Fanon.

The French Caribbean has experienced polarized paths to decolonization: Haiti with its abolishment of slavery and selfproclaimed 'Black' Republic in 1804, and Martinique and Guadeloupe voting for full integration into the French administrative system of departments in 1946. Whereas the first example points to a forceful and drastic decolonization precognizant of the 'natural' path to independence featuring most of the Caribbean countries in the $2 \mathrm{O}^{\text {th }}$ century, the second appears instead as consent to prolonged colonialism. However, the latter choice is more complicated than it might indeed appear. In fact, it is the result of a long struggle between races corresponding to social classes upholding or not the concept of civic nationhood promoted by the French Revolution, which emerged as the founding principles of French Republicanism. The push for integration called for egalitarianism and rejected the hierarchical and racist colonial legacy of plantocracy. Nevertheless, this particular political evolution in the French Caribbean was not harmless. On the contrary, it originated from a series of 
controversies and dilemmas (while producing its own controversies), embracing not only the same proponents of departmentalization, but also those who had never considered such an option as a viable decolonization path. Concepts of race and nation in relation to colonization and decolonization are still current, and were notably present in the intellectual works of great figures such as Aimé Césaire and Frantz Fanon: two Martinican 'rebels' fighting against colonization who embraced different conceptions of decolonization.

In order to understand the political evolution experienced by Martinique, an exploration of its pre-1946 society is necessary. ${ }^{1}$ Besides having the same features of Caribbean colonial societies such as an extractive economic schema founded on slavery, labour exploitation, as well as persisting racial social differentiation, the role of the metropolitan state as a mediator of social conflicts was peculiar to the French Caribbean. Social dissent regularly erupted on the onset of the sugar plantation working seasons, and always resulted in violent repression on the part of the authorities. However, the French State, especially after the abolishment of slavery in 1848, while still preserving the economic and political interests of the békés (white elite), increasingly played a mediating role in ensuring a 'social' peace between conflicting parties. Playing such a role was made possible by the widening gap between the political outlook embodied in the old plantocracy (based on strict racial differentiation) and the Republican political discourse (based on the egalitarian principles of the French Revolution).

The very struggle between reactionary conservatism and republican democracy that marked French political history since the Great Revolution until Vichy - a struggle which could be argued still exists today in the form of civic versus ethnic nationhood - was the dialogical opposition between the Creole elite and the centre's government, as well as between the elite and the local discriminated population. Whereas the conservative Creole elite leaned on political autonomy from the métropole to assert its own socio-political influence over the Caribbean territories, the supporters of a more equal society upheld the civic nationhood principles that the French Republic embodied. This peripheral opposition of visions indeed translated in their attitude toward the centre: one stressed autonomy from it, the other, for inclusion. Therefore, the departmentalization

\footnotetext{
1 For the historical review of pre-1946 Martinique, see Alain-Philippe Blérald, La question nationale en Guadeloupe et Martinique, (Paris : L'Harmattan, 1988).
} 
choice that the Martinicans overwhelmingly voted for does not appear that paradoxical based on the above rationale. All the more that this choice was made apparent in the immediate aftermath of World War II, that is, after the Vichy regime had tangibly expressed its social 'revolutionary' approach in the Caribbean. This was done through an overt racial politics of coercive imposition of French white supremacy in all aspects of life, including in institutional, economic and cultural realms. Even the black middle class' status, which had managed to carve out its own social and economic space in the Caribbean, was undermined during this period, hence the need for a more 'inclusive' stance toward the centre so as to prevent such threats from emerging again. The factor of mimicking French values determined social exclusion or inclusion and animated the choice of departmentalization, as a way to attain egalitarianism according to a civic meaning of citizenship and to fully reject the colonial social relationship based on purely racial supremacy. This willingness to be included into the colonizer's administrative state system and its civic egalitarian foundation did not arise, however, without first attempting to culturally assert the importance and the value of being 'black'. Aimé Césaire's négritude movement can, in part, be interpreted this way.

This literary and broadly cultural movement that Césaire initiated as a student in Paris during the 1930s with other French 'colonized' nationals, such as Damas and Senghor, is generally seen as the attempt to construct a universalistic black consciousness, regardless of local peculiarities defining a given nation. ${ }^{2}$ It went far beyond the 'negrophilia' which featured prominently in France at that time, with culturally simplistic denotations defining blackness (i.e. "inherent rhythm" etc.). ${ }^{3}$ The African ancestry of the former slaves as a shared legacy, and the historical subjection to the Eurocentric socio-political and economic order produced by colonization, were both pointed to as defining features of black identity. In order to counteract and confront the white 'construction', négritude's proponents claimed that a 'nègre' construction had to be carried out. The aim of such a construction was threefold: not only to refute the claimed inferiority of the black vis-à-vis the white, reject

\footnotetext{
2 Pierre Bouvier, Aimé Césaire et Frantz Fanon : Portraits de décolonisés, (Paris : Les Belles Lettres, 2010), pp 59-75. Césaire's poetical 'manifesto' is Cahier d'un retour au pays natal (1939)

3 David Macey, "Frantz Fanon, or the Difficulty of Being Martinican" in History Workshop Journal Issue 58, 2004, pp 212, 214
} 
the colonial social relationship, but also to eventually neutralize such an opposition in view of a universalistic notion of citizenry. The latter aspect was obviously considered to be more utopian than actually feasible. However, building the foundations for a black legitimacy and equality in terms of political rights and peculiarity in terms of cultural identity, detached from the inherent racial eurocentrism, was certainly a pressing and useful enterprise. This attempt of defining 'negritude' however triggered many criticisms among black intellectuals, particularly by Frantz Fanon.

Not only was négritude seen as a white-derived exercise to define what white was not, but it was also deemed useless in that it did not effectively attempt to define what a Caribbean identity meant. Fanon pointed to blacks who had been 'assimilated' by whites, embracing their set of values, therefore implying their own inferiority. In some ways, he was attacking the very social milieu from which he derived. For Fanon, cultural attempts to define blackness followed the white set of values and were also too naïve in their promotion of a primordial black pureness before colonization had tarnished it. This critique was made stronger as it specifically referred to the general inability to achieve true independence from the colonizer by having opted for integration. Fanon's Black Skins White Masks was published in 1952 after the departmentalization of Martinique, and the experience of a growing cultural and institutional assimilation, otherwise seen as a persisting colonization by its critics.

Fanon certainly was not seeking to define a specifically Martinican national identity but rather he believed that decolonization could only be possible through a social revolution, lest a replication of colonial patterns and practices continue. Fanon of course famously held that resorting to violence could be used as a vehicle to achieve this. ${ }^{4}$ In this view, the natural agent for change was the proletarian class, both rural and urban, because as discriminated and oppressed subjects, they were untouched by the white assimilationist trend of conformism. However, Fanon was not the only one criticizing the effects of assimilation, as the leading proponent of departmentalization, Césaire, rejected the move favoring more autonomy. Dealing directly and locally with Martinican politics, by acting both as mayor of Fort-de-France

4 Claudia Wright, "National Liberation, Consciousness, Freedom and Frantz Fanon" in History of European Ideas, Vol. 15, No. 1-3 (August 1992), p432 
(1945-2001) and deputy at the National Assembly (1946-1993), Césaire in contrast to Fanon had a greater stake in the political evolution of departmentalization. He chose first to leave the Communist Party in 1956. He did so following the Soviet repression in Hungary, but his political act was directed especially against the lack of attention that the Communist Party was dedicating to the increasing problem of national identity. The French centralizing State asserted even further its institutional trends of harmonization of all its departments by denying cultural peculiarities. If this trend was felt already as a threat to particular metropolitan regions such as Corse or even Bretagne, the 'nègre' Césaire considered it even more dangerous to the Caribbean peculiarity of Martinique.

Martinique as a product of colonialism and a multi-ethnic polity (clearly not predominantly white), geographically distinct and distant, was still treated without any cultural exception. French assimilation tended to override all distinctions by offering a strict Eurocentric model of education and consumption. Moreover, the paternalist attitude of the French government was expressed by the exclusively economically oriented perspective on Martinique, a strategy which did not take into consideration cultural autonomy. Giscard d'Estaing's discourse well exemplifies such attitudes, which reflected the Republican and Gaullist right that upheld the principle of the French State's centralizing uniformity, flattening all forms of peculiarity. 5

Economic subsidization that did not actually promote economic self-sustainability further deepened a dependency, reminiscent of colonial patterns of centre-periphery relationships. Although such trends towards assimilation were increasingly felt as a continuation of colonialism, Césaire never outright supported independence, as he did not consider Martinican national consciousness sufficiently mature. What he opted for instead was a political language leaning towards more autonomy in the sense of regionalization and decentralization. His support for the Socialists through his Parti Progressiste Martiniquaise (PPM) is evidence of such an autonomist discourse in contrast with conservative assimilation or radical independence. However, after Mitterrand's

5 A-P. Blérald, La question nationale en Guadeloupe et Martinique, p120. "Naturellement, la poursuite du développement économique et social, c'est la tâche prioritaire à laquelle la France, avec ses citoyens des Antilles et de la Guyane, s'est désormais consacrée. " 
election in 1981, he chose to 'freeze' the autonomous discourse by supporting the socialist government in its quest for economic development for Martinique in his famous "Discourse on Moratorium". ${ }^{6}$ The separation between the poet of négritude and the pragmatic politician was obvious, albeit coherent in that Césaire supported greater equality by demanding greater peculiarity within the same institutional framework.

Such a perspective was not one echoed by Fanon, who had, as already mentioned, a more radical understanding of the relationship between the colonized and colonizer. Not only did Fanon refuse to support a 'nègre' definition of national consciousness (as it hinted to an inverted racism instead of embracing a 'Creole' identity), but he also rejected the normative hope for civic universalism through revolution. This perspective derives from his own work as a psychiatrist, where he had the opportunity to test the psychological maladies of colonized patients, undermined in their very essence by the colonial legacy of social organization. They had been 'alienated', not only by the arrival of the colonizers, but also by their persistent disguised colonization through cultural assimilation, for example. The very act of speaking an imposed language was a submissive act confirming an unbalanced relationship, obliterating all forms of indigenous expression. ${ }^{7}$ For Fanon, the only way to remedy this alienated state was to reject the colonizing element, and that could only have been possible through liberation, not simply nationalistic but also mental.

Whereas Fanon supported revolution, even a violent one if necessary, Césaire rejected it as merely a heroic moment which had to be followed by realistic calculations regarding political and economic survival. ${ }^{8}$ Was Césaire himself so assimilated that he upheld the French 'white' discourse of black Martinicans' inherent inability to survive? Although one could claim that he was pragmatic

\footnotetext{
6 William F.S Miles, "Metaphysical considerations can come later, but the people have children to feed" in French Politics, Culture \& Society, Vol. 27, No. 3 (Winter 2009), p2

7 C. Wright, "National Liberation, Consciousness, Freedom and Frantz Fanon" in History of European Ideas, p429

8 Justin Daniel, "Aimé Césaire et les Antilles françaises: une histoire inachevée ? " in French Politics, Culture \& Society, Vol. 27, No. 3 (Winter 2009), p33
} 
in his approach regarding the feasibility of independence, this question nonetheless remains open to interpretation.

It has been argued that French departmentalization as a path to decolonization appears more complex and rational than a mere unwillingness to gain political independence. The peculiar relation between the French State and its colony, and the relation between white elites and the larger population, made the possibility for integration more likely than in other Caribbean contexts. The revolutionary tradition of France and the struggle between two opposing concepts of nation also facilitated the equation of egalitarianism with decolonization. The discourse of négritude, chanted by Césaire, derived from this need to express this equality between whites and blacks by stressing differences. Once able to express such differences, it was easier to uphold egalitarianism within the institutional framework of the French State.

The very need to express this egalitarianism within the same context hints at the hegemony of white minority oppression over a black majority under colonialism. Departmentalization however, resulted in a renewed, disguised cultural assimilation/colonization by an increasingly centralizing state. Local peculiarities were discarded in the name of a uniform state, where euro-centrism remained the founding cultural assumption to the detriment of uniquely Caribbean identity formations. Tensions between a departmentalization which called for more autonomy and the preconditions of economic development necessary to sustain such autonomy are significant in understanding Césaire's political actions. Fanon challenged such solutions to decolonization by stressing the inherent alien and alienating impact of the colonizer. Regarding race, the construct of négritude was set along the white construction of the other, and eventually pointed at a reversed racial stance, without considering the unique, multi-ethnic and social experience of Caribbean peoples. The assimilation's results threatened the birth of an independent self-consciousness as it was an institutionalized continuation of colonialism. For Fanon, in order to gain meaningful independence, the only solution was national and mental liberation from the colonizer. What emerges from these two different intellectual discourses on race and nation is the complex and multilayered nature of colonial contexts, where more than one solution are provided as possible paths toward decolonization. 
Works Cited

Blérald, Alain-Philippe. La question nationale en Guadeloupe et en Martinique. Paris : L'Harmattan, 1988.

Bouvier, Pierre. Aimé Césaire et Frantz Fanon : Portraits de décolonisés. Paris : Les Belles Lettres, 2010.

Césaire, Aimé. Cahier d'un retour au pays natal. Éd. Dominique Combe. Paris : PUF, 1993.

Daniel, Justin. "Aimé Césaire et les Antilles françaises: une histoire inachevée? " in French Politics, Culture \& Society, Vol. 27, No. 3 (Winter 2009), pp 24-33.

Fanon, Frantz. Peau noire, masques blancs. Paris : Le Seuil, 1965.

Macey, David. "Frantz Fanon, or the Difficulty of Being Martinican" in History Workshop Journal, Issue 58, 2004, pp 211-223.

Miles, William F.S. "Metaphysical considerations can come later, but the people have children to feed" in French Politics, Culture \& Society, Vol. 27, No. 3 (Winter 2009), pp 63-75.

Wright, Claudia. "National Liberation, Consciousness, Freedom and Frantz Fanon" in History of European Ideas, Vol. 15, No. 1-3 (August 1992), pp 427-434. 